座 談 会

\title{
バイオテクノロジーと紙パルプエ業
}

木材科学委員会

\section{Round Table Discussion}

\section{Bio-technology for Pulp and Paper Industry}

\author{
Wood Science Committee
}

この座跀会は木忉利学歪只会セミナーの一德として 昭和 59 年 10 月 30 日に開倠された。其門委员として 御出席下さった下记の才文

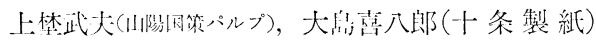

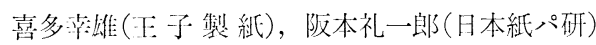

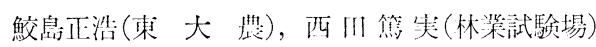

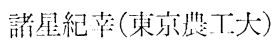

に厚く御礼中し上げるとともに，程極们に御発言をい ただいた木材科学系只全委員の力々にも感謝いたし去 す。座談会のテープ興しは飯㓐管介委员の大変な努力 に基つくことを記し謝觉を表します。

\section{はじめに}

中野 ただいまから「バイオテクノロジーと紙パルプ

工業」と題する座淡会を始めます。本日はこの分野 の第一線で活躍して扮られる産・官・学の 7 人の方 々に専嗄积員として御参加いただきました。御多忙 にもかかわらず御集りいただきすしたことを厚く御 礼け儿上げます。

さて，これからの座腅会ですが私は「バイオテク ノロジー」といら名称に父後れを感じまして，実は 「微生物と紙パルプ丁.率」に变えようかとも思った わけです。しかし，それでは怵木赭が入らないこ とになります。最近，私は「バイオテクノロジー」 に関して，三，三の小胢了を境んでみました。これ らを通して私が理解した「バイオテクノロジー」と は，細胞融合技術（細胞丁学）及び遗伝子組又替光 技術（遗伝子工学）とこれらを生座につなぐ物質生
産技術（例えばバイオリアクター）といらことにな ります。したがって皆さん方の発言の多くは「バイ オテクノロジー」の出発点の部分からなり，その将 来の発展の方向のなかに「バイオテクノロジー」が あると考党るわ怰で。

このよらに「バイオテクノロジー」を位置づけて 座㡣会を進めたいと思いますので，よろしく御願い 致します。この分野では私は全くの素人ですが司会 をさせていただきます。

\section{1. チップ劣化}

中野まず「チップの少化」から討論をはじめましょら。 御承知のように紙パルプ産業にとってチップの劣化 は重大な問題であると言われていながら十分な検討 が行われていないよらにも思われます。最初に原口 先生から話題提供といら意味で御発言を願います。

原口どのような微生物がチップ少化にかかわってい るか，といら点に絞って招話してみたいと思います。 オーストラリアの H. Greaves はパプアニューギニ アのメダン及びバニモで実際に近い野積みチップ (12 $15 \mathrm{~m}$ 径 $\times 7.5 \mathrm{~m}$ 高) を用い, その中の微生物 の種類，分布を調べています。チップパイルの中は 温度が $60^{\circ} \mathrm{C}$ にも達しますし, 相当に湿度も高いの で，そのような環境に適する微生物が繁殖するわけ です。その種類も不完全菌類 (Fungi Imperfecti) の Aspergillus, Humicola, Penicillium など, 子の う菌類 (Ascomycetes) の Chaetomium, Thermoascus など，担子菌類 (Basidiomycetes) のSchl- 
zophyllum, 放線菌類 (Actinomycetes) の Streptomyces など，極めて多種にわたります。

興味深いことにチップパイルの部位によって螀っ た菌が繁殖しております。中心部には好熱菌といわ れる Chaetomium, Thermoascus などが，またそ の外側には耐熱菌に属する Aspergillus, Streptomyces, Pseudomonas などの菌が繁殖します。

これらの菌がチップに及ぼす影響は変色, 重量娍 少あるいは紙力低下といらようなものです。

飯塚 非常に多くの菌がチップの劣化に関係している ことはよく分りましたが，実際に最も注目しなけれ ばならない菌には，どんな菌がありますか。

原ロ パルプ原料としては軟腐朽を起こす菌が最も問 題であるとい学ます。なかでも高温・高湿で生苚す るChaetomium などが最も警成すべきものです。

中野 微生物によるチップの口スは実際どのような面 で，どれぐらいあるのか，もら少し具体的祱明し ていただけませんか。

臼田 チップパイルに拈るチップの少化といっても 気温，雨量あるいは樹種などによって異るため，一 概には申せませんが平均的には 6 ケ月間の貯蔵で谷 積重の減少が 4 〜 \% 程度だと思います。劣化が大 きい例としてはユーカリチップを 6 ケ月貯蔵した場 合にチップの容積量の減少が $11 \%$, カッパー価 16 〜 18 でのパルプ収率が 50\% から $24.3 \%$ に低下する といった例も我が国のM社から報告されております。

微生物は私の専門ではありませんが、幾つかの報 告をみる限りチップパイル中の温度は $2 \sim 4$ 週間内 に $60^{\circ} \mathrm{C}$ 近くまで上昇し，そのために大半の微生物 の活動は停止すると考兄られてます。そしてチッ プの劣化は主として酸素酸化や，生成した有機酸に よる酸加水分解に起因するとされています。先ほど の原口先生の括話とちょっとらがうのですが，これ は実験条件の違いによるものかもしれません。

原口 確かに $60^{\circ} \mathrm{C}$ 位になりますと通常の菌は繁殖し

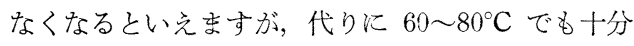
に生育する菌が繁殖しはじめてきます。そのため特 に南方地域にはチップの少化が非常に激しいといわ れています。

喜多ただいまの归田先生のお話はユーカリチップを 貯蔵した場合のことでしたが，それはユ一カリに特 異的な結果といらことはあり得ませんか。

臼田 確かに，その可能性はあると思います。米国な どの針葉樹材を用いた場合の結果では，先ほど私が 申しました注どの劣化は認められて物りません。

上埜 私どもの経験では，同じニーカリでも抽出物と

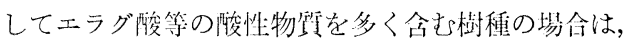

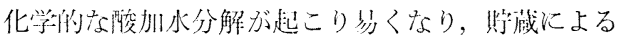
チップのロスが北常に多くなる仃能性があります。 しかし，その他のポリフェノール等を多く含む樹種 では，それはどではありません。

中野 チップのロスは樹種，父倠”，嘼葴期間や方法な ぞの条件によって琴なるものの，やはり微生物によ るチップの少化は問題と想いますが，これを防止す るためのチップの防腐剂処理は行われているのでし ょらか。

原口 实際に行わ机ているかどうかは份じませんが， 処理は可能だと思います。

鮫島 チップの少化は紙質の而からみた埸介、どのよ らな影響を与えるのでしょうか。

臼田 米国でスラッシュパインやサザンパインを対象 にして䂠究された結果ですが，48週間の眝蔵でチ ップ重量は $8 \%$ \%娍少しますが，パルプ収率には変化 は認められません。しかし，紅打には約 20 週間の 貯藏段階から，亲ず引き烈溞度の低下といら形で影 響が出てまいります。このような絬果は调枯する地 域によって変わってくると思います。

中野 それでは「チップ少化」のしめくくりとして， 海外からのチップ輸送中の期間を利用し，パルプ化 の補助としてリグニン分解菌による処理は可能でし 上らか。これは後の話題である「バイオロジカルパ ルピング」に関連することですが。他の微生物によ る処理の可能性はいかがでしょらか。

飯塚 リグニン分解菌ではありませんが，チップ輸送 の期間を利用してへミセルロースの還元末端基を微 生物的に酸化し，アルドン陵末端にすることができ れば，パルプの岑水化物収涪の问上につながると思 います。こういった力们で碑当な菌をスクリーニン グしてみるのも面白いと思います。

中野 チップ輸送中にリグニン分解菌で処理すること は将来的にみて如何でしょらか。

西田 現実的に可能かどうかは分りませんが，技術的 にはチップのガス減茠もできますので川能だと思い ます。

喜多 米国西海苹と日本との間のチップ輸送の所要時 間は約 2 週間で，リグニン分解菌による処理を行う には適当な期問であるとい学ます。将来，こういっ た処理を行らとすれば，チップ輸送中に行らのが適 当だと思います。

\section{2. リグニン生分解の化学}

中野 リグニン分解菻の倸が州屯したところで，話題 
を「リグニン㤋分解の化学」に移します。

石原 リグニン特分解の化学:いつて，一百に述べる ことは行罧ではありません。この方面の研究には生 菌を用いるものと，醉素を朋いるものがあります。 生菌を用いるときは，生菻の作用による木材あるい はリグニンの変化を観察し，そ机から実際に作用し ている酵菜を推定するわ孙です。一方，生菻による

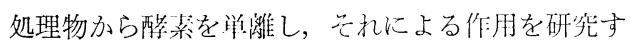
ることも行われています。もっとも，これはまだ緒 についたところですが。

生菌を使った硎究を行う際に，汪意しなければな らないと私が常に想っていることがあります。それ は自然条件とかけ離れた培善条件を採用して研究し た場合，窝に天然状態ではどうなのかを考息る必要 があるということです。天然状態ではリグニンだけ 単独に存在することもありません。天然状態にはな

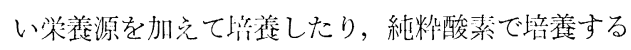
ことは，硎究としては興味あることですが，必らず 最後には天然状態ではどらなのかを考える必要があ ると思います。

諸星 ただいまの不原氏の扣話に全く同感です。特に リグニンは天然畐分了化合物であり, 自然界の炭素 サイクルの一側面を担ら物質であることから, リグ ニン生分解は自然の巧妙な物質流転の循環システム の中で行われているといら観点で，まず理解される ベさでしょら。

そこで，自然界で微生物による大然りグニンの変 化の様子を見ると，少なくとも腐朽材の重量減少摔 $60 \%$ 程度までは，桨香核間の胵化重縮合反応は見ら れず，各リグニン構造単位が平均的に分解されてい くといら結果が得られます。同時に, 遊離フェノー ル性単位を量的に伯って行きますと, 腐朽度の增加 に伴い增加している事実が見いだされます。このこ とはエーテル結合の開裂反応を示すものと思われま す。いずれにしても，このよらな事実は適当な酵素 系を用いることにより, リグニンの生分解は可能で あることを示唆して抢ります。

次に，こういったリグニン生分解反応を利用する に際してですが，生菌白身を実際に利用していくこ とはなかなかむずかしい面が多いのではないでしょ らか。さしろ㳦体から得られた䣼素系を利用して行 く方がより実現性が高いように思われます。

私達はカワラタケ菌体外粗酵素を用いて, 天然り グニンの分解の様子を見たことがあります。その結 果はモデル化合物を用いた場合とかなり異なり，分 解は遊離フェノール性该位で集中的に進行し縮合型
棈道量にはほとんど変化が見いだせませんでした。 このことはりグニン分解醏素系の一つであるフェノ ールオキシダーゼ類の関与を示しています。ちなみ に分離精製したカワラタケラッカーゼは, 遊離フェ ノール性水酸基を持った $\beta-0-4$ 型モデル化合物を 非常に速かに分解しますが，非フェノール性構造単 位は全く分解しません。他方 K. Kirk (林産試験場, マジソン，米国）らは Phanerochaete chrysosporium から得たりグニン分解醏素が特異的に非フェ ノール性構造単位を分解すると報告しています。こ のようなまちまちな結果は, リグニンが多様な化学 絬合様式を持った複雑な物質であるため，これに作 用する酵素系も多岐にわたっていることを示すもの かもしれません。

中野 他に御発言があれば願います。

鮫島 ごく最近になってリグニンの生分解を遺伝子・レ ベルでとらえて行こうという動きがあります。こう いう研究は，まだ日本では見られませんが, Oregon Graduate Center (米国) の M. Gold は Phanerochaete chrysosporium のミュータントを用いて, リグニン分解活性の発現について研究しています。 今一つはマンチェスター理工科大学 (英国) の P. Broda 等の研究があります。彼等はやはり Phanerochaete chrysosporium を用いて，リグニン生分解 に関する酵菜系の解明と, 酵素の生産をつかさどっ ている遺伝子のクローニングの仕事をして居ります。 リグニンの生分解には非常に多くの酵素が関与し ていますので，その遺伝子の発現に関しても恐らく 幾つかのブロックに分かれていると思います。その 西たりの大凡そを理解することが生分解の全体像を 知るらえで重要ですし，そのためにはミュータント などを用いて酵素系の発現に関する研究をもっと行 う必要があるとい充す。

Broda 等が行っているリグニン分解酵素のクロ ーニングの詳細については複雑になりますので省略 しますが，このような方法が開発されますと，言替 えれば木材腐朽菌の遺伝子を大腸菌あるいはもっと 酵素生産に適した菌にクローニングすることが出来 ると，木材腐朽菌から少量しか得られなかった酵素 を大量に得ることが可能になります。酵素を用いた 研究, あるいは醉素を用いたバイオロジカルパルピ ングなども，ずっと考党易くなります。

西田 大腸菌に木材腐朽菌の遺伝子をクローニングし ようとしているという扣話でしたが，大腸菌にクロ ーニングした場合, 菌体外に酵素を出さないのでは ないですが。 
鮫島 確かに大腸菌の場合は菌体外に酵素を出しませ ん。Broda 等は遗伝子の解析が行いやすいので大 腸菌を用いているのでして，将来は何か他の菌を使 って酵素を作らせて行くことになると思います。

西田 実際に，リグニン分解能を発現しているか否か のチェックは，どのようにしているのでしょらか。

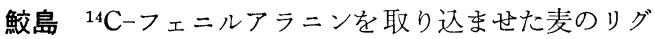
ニンを単離し，これに菌体から得た粗酵素液を作用 させたときに ${ }^{14} \mathrm{CO}_{2}$ が発生するか否かを調べて，リ グニン分解の有無の指標にしています。

中野 リグニンの生分解に関して，何か他に御意見は ございませんか。

喜多 マンチェスター大学の研究グループのスポンサ 一として British Petroleum がついていると言わ れています。これにはどういう背景があると思われ ますか。

鮫島 リグニンの生分解と石油系の炭化水素の生分解 は共通する点も多いと思いますし，それにやはり遠 い将来を考えて，何か考えがあるのかも知れません (笑い)。

\section{3. バイオロジカルパルピング}

中野 次にバイオロジカルパルピングについて話して いただきたいと思います。

西田 バイオロジカルパルピングは，もともとスウェ ーデンの K. Eriksson や T. Nilsson 等が腐朽材 から分離した或る種の菌を木材チップに加えて腐朽 処理をしたのち，機械パルプを製造したところパル プ化が容易であることが見い出されたことに始まり ます。

しかし，実際にチップを微生物で処理してから MP P TMPをつくりますと, 微生物処理によっ て繊維に断点が出来るせいか, 短繊維やファインの 生成が多くなります。また，へミセルロースも失な われやすくなります。私達も Phanerocheateや Sprotrichum 等の菌を用いて検討はしていますが, 現在のところエネルギー消費の面では改善出来るも のの，紙質の面で問題があるといらのが実情です。 な和腐朽処理そのものにつきましては，菌を直接チ ップに接種するのではなく，胞子䀣濁液にチップを 浸漬する方法で行いますと, 約 1 週間でチップ全体 に菌糸がまわった状態となります。

今一つの微生物前処理の可能性として, 微生物処 理による断点の生成を逆に利用して薬液の浸透性を 高め SCP 法等の改善に結びつけるといら夢もあり ます。
中野 バイオロジカルパルピングに関して何か御発言 がありませんか。

喜多 微生物処理をMPの前処理として考学る場合 $\mathrm{N}$ 材に関する知見に乏しいといえます。腐朽菌や材の 特徵かもしれませんが，もっと $\mathrm{N}$ 材についての基礎 的な知見が必要でしょら。またMPの品質改善に利 用出来ないかという考光もあるようですが，それに 要する大容量の装置，処理時間を考えた埸合，生菌 ではやはり無理だろらと思います。

微生物前処理によってチップの薬液浸透性を改善 したりリグニン・炭水化物結合を選択的に切断出 来れば，脱りグニンを促進することも出来ます。乙 かし現状では木材細胞譬の二次壁，細胞間層などの 部位によるリグニン化学構造の相違を考えて，それ ぞれのリグニン構造に最も適した菌や酵素をスクリ ーニングするための Assay 系の開発といった基礎 的な研究がまず必要でしょら。

大島 自然界の木材の腐朽は算一な菌ではなく, 泥合 フローラによって分解されているわけです。言い換 えれば，幾種かの菌のもつ酵素系によって，リグニ ンは分解されているわけで, リグニンの各々の化学 構造に最も適した基質特異性をもつ酵素を見い出し て利用して行く必要があると思います。単一の菌自 身を用いるのでは，やはり無理でしょう。

中野今までの御意見から伺えますことはバイオロジ カルパルピングの実用化には，まだまだ時間を要す るといらことです。どらすれば少しでも実用化の時 期を早められるか，といら点について御意見はあり ませんか。

西田 バイオロジカルパルピングの問題点は大体出つ くしているのだろらと思います。そして，それらの 多くは良い菌が見つかれば基本的には解決するでし ょう。しかし問題は紙パルプ工業と食品工業などと の間の根本的な差にあります。最近 Eriksson 教 授（スウェーデン）からセルラーゼ活性をもたない リグニン分解菌の変買株を見い出したと知らせて来 ました。こういった特定の菌で，あれだけ大量の木 材なり，パルプなりを処理することが可能か否かと いうことになると思います。

鮫島 チップを菌で処理する場合，実際問題としてチ ップに附着した菌体がパルプ品質に悪影響を及ぼす か否か，あるいは菌によってチップ全体を均一に処 理することが出来るか否かといった点を明らかにす る必要があると思いますが，いかがでしょうか。

大島 日本のように高いパルプ品質が要求されるとこ ろではチップに菌体が附着していることは，確かに 
望ましいことではありません。もちろん，どのよう なパルプ化法を州いるかにもよりますが。

西田 菌処理の均一性についてですが，これはかなり 難しい問題だと思います。

鮫島 バイオロジカルパルピングを菌によって行うこ とは難しいということになりそうですね。そうかと いって，不安定で製造コストの高い醅素を，極めて 大量なチップの処理に用いることも困難なことだと 思います。

将来酵素に関寸る研究が一周進展した段階で, 酵 素の構造を模した高活性触媒が開発されると思いま す。これを利用するのが一番期待出来ると思らので すが。

西田 私も全く同感です。

臼田 以前, 近藤民雄先生（九大名誉教授）が紙パ技 協誌 (31 卷 6 号) に，シイタケのホダ木のパルプ化 について書かれていました。どこかの会社で実際に パルプを製造していると書かれていたよらです。ま さに，これなどは一石二鳥のバイオロジカルパルピ ングではないでしょらか。

石原 確かに, 現在のキノコ産業は 200 万 $\mathrm{m}^{3}$ の木材 を使用して抢り，2,000 億円産業ともいわれていま すので，ホダ木の有効な利用法があれば非常に面白 いのですが。

西田 実際にシイタケのホダ木で $\mathrm{KP}$ を製造してみま したが品質はあまりよくありません。シイタケ菌に よってセルロースがかなり分解されており, やむを 得ないことだと思いすす。

中野 バイオロジカルパルピングに関しては, 大体御 意見も出つくしたように思いますので，次のテーマ に移りまょら。

\section{4. 排水処理}

中野これからの座談はチップのような固体ではなく 液体に対する微生物処理の問題です。米国ノースカ ロライナ大学の H.-m. Chang 教授等が熱心に仾究 しているのは御承知のとおりです。それでは活発な 御発言を㹉願いします。

阪本 排水の微生物処理としては活性污泥処理がよく 知られています。紙パルプのように比較的有機物濃 度の低い大量の排水を処理するのに適した処理法で あり，凝集沈澱処理と組み合わせて効率よく污濁負 荷が除かれています。更に欧米諸国では漂白工程か ら排出されるごく微量の樹脂酸, 脂肪酸, フェノ一 ル類及びそれらの塩素化物が焦類に影響を与えると して問題視して扣ります。これらも活性污泥処理で
效摔よく分解されますので，米国でも最近かなり䕖 入されています。一方，北欧では閉鎖水系であるこ とや，気候的関係からか活性污泥処理があまり有効 ではなく，塩素を使用しない方向にあると聞いて抒 ります。な抏，非常に興味深いことは天然には存在 しない塩素化合物でも微生物は分解出来るといらこ とです。このような微生物の持つ大きい可能性がバ イオテクノロジーの一番の魅力ではないでしょら か。

中野 フィンランドなどでは現在すでに塩素の使用を やめているのですか。

阪本 その方向に向けて変わりつつあるというところ だと思います。

中野 次にメタン発酵について御発言を願います。

上埜 私は昭和 57 年から今春まで工場のメタン発醭 プラント関係の仕事をして来ましたが，その際の経 験を中心に括話します。処理している水は SP の工 バポレーターの凝縮水及びタンパク酵母から核酸を 抽出した排液からなって拉りまして水量 $2,400 \mathrm{~m}^{3} /$ 日，有機物量は CODCr $28 \mathrm{t} /$ 日です。

このような水をメタン発酵で処理することにより， 排液処理とともに濃度 $60 \%$ のメタンガスを 15,000 $\mathrm{m}^{3}$ /日回収して扮ります。私どものメタン発酵は 53 $\sim 55^{\circ} \mathrm{C}$ で行う，いわゆる高温発酵で， $35^{\circ} \mathrm{C}$ 程度の 中温発酵に比較して, 滞留時間を短縮することが出 来ます。

メタン発酵の問題点として次の点が揭げられます。

（1）滞留時間が排水によって異なりますが，中 温発酵の場合よりも短時間とはいらものの, 2 日間又はそれ以上と長い。これを好気性発 酵程度にまで短縮できないか。

(2) $\mathrm{pH}$ 管理を厳密にする必要がある。私ども の場合は $7.2 \pm 0.1$ に調節しています。

(3) 発酵慒内の温度を $50 \sim 56^{\circ} \mathrm{C}$ に保たねばな らない。夏季には冷却する必要があります。

（4）処理水中にはいろいろな形の硫黄分が含を れて打り，これがあまり多量ですと生成した $\mathrm{H}_{2} \mathrm{~S}$ が槽内に蓄積して障害となります。

（5）槽内の排液の酸化還元電位を一定の範囲に 保たねばならない。これは管理上重要な指標 です。

中野 メタン発酵は既にパルプ・紙工場で実用化が始 まっているわ忛ですが，今後広く普及して行くこと を期待いたします。

排水処理に関しては脱色，消泡あるいは脱臭を目 的とした微生物処理の可能性がいわれておりますが, 
この点について何か御発言はありませんか。

臼田 パルプT埸の排水に高い発沦性があることが知 られて扣りますが，私達は活性污泥処理によって， この発泡性を抑えることが出来るか否かにつき検討 しました。その結果, 最も発泡性の大きな塩素段排 水の発泡性を約 $1 / 7$ にまで低減出来ました。

西田 私は以前パルプ排水の脱色について研究したこ とがあります。単子菌類を用いますと80～90\%の 脱色をすることが出来ます。しかし，この時点での 問題は単子菌類の栄養源として糖類を添加しなけれ ばならないので経済的に成立するか否かという点で した。

この点に関して米国の H.-m. Chang 教授らがパ ルプ工場のスラッジを栄養源として Phanerochaete 類の菌丵膜を用い，散水口床的に排水を処理し効率 的な脱色に成功していることは非常に興味深いこと とい党す。この場合とくに糖類を添加する必要は ありません。それは，この菌類が高いセルラーゼ活 性をもっているからです。

話が厌りますがメタン発醉はコスト的にはどらな のでしょらか。

上埜 排水の種類によって異なって来ると思いますが， 私達の限られた経験をもとに括話しいたします。メ タン発酵には排水処理とメタンという燃料を生産す る二つの目的があります。仮りに燃料生産だけを目 的として考皇た場合， C重油の価格が 50,000 円 $/ \mathrm{t}$ 以上であればメリットが出てまいります。もちろん， この他に排水処理といらメリットが加わることにな ります。

原口 発酵慒内の菌相は培荃条件等で異なって来るの でしょらか。

上埜 高温発酵と中温発酵では菌相が異なりますし, 処理する水の中の有機物の種類によっても異なって くるように思います。

喜多メタン発酵の問題点の一つとして, 処理時間が 長いことが指摘されましたが処理の高速化を目的と して菌体の固定化を検討されていますでしょうか。 上埜 最終的に高速化に結びつくか否か分りませんが， 菌体の固定化は検討されているようです。

\section{5. 脱臭処理}

中野 微生物を利用したクラフト臭気の除去について 御発言いただけすすか。

西山クラフトパルプ製造工程で生成する恶臭成分と しては硫化水素, メチルメルカプタン，硫化ジメチ ル，二硫化ジィチル等が知られています。私どもの
白河丁場では臭父発生源として特に問題である蒸解 釜からの凝縮水（木釜ドレン）と真空蒸発们で発生 する凝縮水を対象に活性污泥処理による脱臭処理を 行っていますが，90\%以上の効獄で脱臭出来るとい ら結果を得て扣ります。

喜多私どもも凝縮水を対象に脱息の効摔アップを日 的として研究を行いました。硫化ジメチル，二硫化 ジメチル，メチルメルカプタンといった悪臭物質は， 処理によってジメチルスルホンやメタンスルホン酸 に変化して無臭化されるわけです。私どもの結果で は脱臭に関与する微生物は種々の糸状菌だったわけ ですが，與味深いことにはメタノールの資化性をも つ系状菌が脱臭效率が高いことです。今後の方向と して菌の固定化が出来ればと考えて扣ります。

\section{6. パルプ酵母}

中野 それでは話題をパルプ酵湫します。こはれ 言らまでもなくSP 排液中の糖分の利用です。

大島 パルプ酵母と一ロに言いましても SCP として のトルラ酵母あるいはその他の酵母の生産，関連製 品の生産など多岐にわたっています。トルラ酵母の 生産は今世紀初頭から研究が始められ，既に技術的 に確立されています。我が国では東洋紡犬山工場で 1957 年に初めて企業化されて扣ります。当時は排 液の BOD 低減及び鸰料生産を目的としていたわけ です。

その後, 紙パルプ業界の三社が相次いで SCP の 生産及びそれに関連したファインケミカルスの製造 を目的として実用化し，現在に至っているわけです。 1960 年頃になって核酸系の調味料は，呈味性が強 いことが発見されまして，核酸の供給源としてトル ラ酵母が注目されるよらになりました。これがトル ラ酵母からファインケミカルス製造の初めではない かと思います。

トルラ酵母の生産は最盛期には $20,000 \mathrm{t} /$ 年にも達 しましたが，現在は約 $10,000 \mathrm{t} /$ 年程度となっていま す。これは SCP としての利用が大豆粕などの他の 蛋白源と競合する関係から，あまり期待出来ないこ とによります。今後はファインケミカルスの原料と しての利用が，ますます重要になってくるでしょう。 SCP としての利用について，今少し補足いたし ますと, 現在我が国の配合飼料消費量は 2,400 万t/ 年で, 1 万t/年の SCP は極めて微々たるものなわ けです。ただソ連では数十万 $\mathrm{t}$ ＼cjkstart百万 $\mathrm{t}$ も $\mathrm{SCP}$ を生産しているといわれて扣ります。

中野 トルラ酵昌とならんでペキロ酵母が知られてい 
ますが，こ机についてはいかがでしょうか。

大島 ペキロプロセスはフィンランドの紙パルブ佃它 所で開発されたもので, 通称ペキロ菌 (Paecilomyces varioti) が用いられます。菌体が系状を呈して招り， 分離が容伯であり, 経済的にも有利であるとされて います。現在，主として北欧，東欧圈で採用されて 扣り栄差源としてはトルラ䣼母之同等といわれてい ます。

更に，これは央用化されていないと思いますがス ラリー状の原料を単糖にすることなく, 直接菌体に してしまう方法も考えられています。これは先程, 原口先生の括の中にありました Chaetomium 類 の菌を用いるもので大変興味深いものだと思います。 中野 酵母からのファインケミカルスの生産は現在ど のような状沉でしょらか。

大島 唒阷加のファインケミカルスとしては川藏薬 であるグルタチオンが有名です。核酸は主として調 味料原料として $1,000 \mathrm{t} /$ 年程度生産されていますが, 更に各種の医薬品子製造されています。代表的なも のとしてはシチコリン, ウラシル系の制ガン剂など があります。今後，核䐗系の医薬品の開発が進もこ とを期待しております。徒来，水可溶成分のみが検 討されてきましたが，有機溶㷊可溶成分にはまだま だ興味深い物質が多く含まれています。例えばエル ゴステリンは $0.5 〜 1.0 \%$ 程度含まれています。いず れにしても今後の発展は非常に有望だと期待してお ります。

中野 それでは次に排齐物の有効利用に移ります。

\section{7. 廃棄物の有効利用}

石原 最近，パルプエ場にはチップとして搬入される ことが多いのですが，チップを製造している工場で は廃亲物としてバークがでてまいります。それを利 用してバーク堆肥を作ることが出来，最近はかなり 使用されるよらになりましたが，未熟なものを施用 したり，施用しすぎてかえって有害な影響を及ぼす といったことをよく間きます。この原因は大体腐熟 期間が短かすぎることによるといえましょら。

末分解の炭水化物を施用し束すと土壤中で微生物 が繁殖して空螺分をとってしまい，植物の生㕕に有 害な結果を及ぼすことは，古くから知られておりま すが，その意味からも或る期間以上野積みすること が必要です。バーク堆肥の製造で興味深いこととし ては，東北地方のある地域ではバークを家畜の敷料 として利用したのち堆肥を生産しているようです。 家畜のフン承が加わ非常に肥料効果の大きい堆肥
が出来るわけです。

鮫島 バーク倠肥を生産する坸合の一番の問題点とし ては，それが十分に規格化されていないことがあり ます。また前処理方法, 効果的な微生物のスクリ一 ニング，標準的な施用方法の確立などの基礎的な知 見もぜひ必要です。

石原 規格化についてですが今年（59 年）10月 1 日 付で法律（地力増進法）が施行されたと聞いて扣り ますが，規格はこれからつくるという話です。

中野 バークではありませんが，メタン発酔にスクリ ーンリジェクトが利用されていると聞きましたが， いかがでしょらか。

上埜 私どもでは 1 日 $1 \mathrm{t}$ 程度のスクリーンリジェク トをメタン発酵槽に加えています。これは発酵槽内 で部分的に分解して，ある程度多孔質になり，その 䋐維の中に菌体が固定化されているのではないかと 思います。添加量に注意する必要はありますがメ夕 ン発醅の效率を高める上で効果的な方法です。

\section{8. 林木育種}

中野 それでは，材不奇種に移りたいと思います。私 は今秦（59 年），王子製紙の龟山育種場を見学する 機会を得ましたが，パルプ紙工業にとってパルプ適 木を開発・生産していくことは非常に重要な課題で के。

石原 林業試験場造林部で行われている研究の状沉に ついて䉍単に説明します。最も単純なものに，植物 体の二次木部からカルスを生産し（脱分化），次い で再分化させて植物体を生産する方法があります。 この方法は品種改良にはなりませんが，サシ木の困 難なシラカバなどの苗を生産するには有効な方法と なります。この場合，脱分化，再分化は培荃液の組 成を変えることにより，例えば植物ホルモンによっ て行らことが出来るわけです。

葯培羕といら方法もあります。これは本来は半数 体（n）をねらら方法ですが，林木ではまだ成功例 はないよらです。葯中の花粉から半数体を育てるわ けですが，林試でドロノキについて行ったものは現

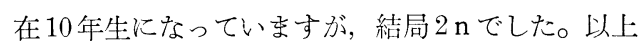
は育種ではなく，単なる増殖といらことです。

育種では細胞融合といら方法があります。二つの 植物体（A， B ）の葉肉細胞を単細胞化しプロトプ ラストをつくります。二種のプロトプラストを融合 させることを体細胞融合といいます。この場合，核 の融合の仕方によって三種の雑種が生まれて来ます。 両方の核が融合する $(A+B)$ 雑種 (異質 2 倍体) 
と，一方の核だけが残り他厅の核は死減してしまっ ても，なお細胞質の中の遗伝因子が残って出来る二 種の細危筫雑種があります。

現在，私どもの造林部ではギンドロとヤマナラシ といら同属の木については，細胞融合には成功した もののカルスにはなっていないといら状況のようで す。つまり $(\mathrm{A}+\mathrm{B})$ 雑種の本当の植物が出来たと は末だ言えないわけです。次にコウゾとミッマタは 科が異なりますが，その場合には融合も出来ない状 態です。要するに高等植物に括ける細胞融合の実用 化は，まだまだ先のことのように思います。まして 遺伝子操作に関しては, 大腸菌の場合とは違い DNA の切り出しも出来ない, ベクターも見つから ないといら段階でして, 夢のまた夢といら状況だと 聞いて括ります。

喜多私どもの龟山䏍種場でも，この種の研究を行っ ています。研究の目的は繊維植物, とくに南方系の 早生樹種をパルプ適木に改良することをねらってい るわけです。通産省の補助金を得て，一応昭和 57 年から昭和 61 年の 5 年間の研究プロジェクトとし 、実施中です。

現在アカシア属, ニーカリ属, マッ属を中心に 40 種以上の樹木を材料として研究を行って扣りま す。葉肉細胞からのプロトプラストの単離はアカシ ア属, マッ属ではうまくいっていますが, ニーカリ 属ではうまくいっていないようです。カルスからの プロトプラストの単離は大部分の材料でうまくいっ ているようです。手法としては細胞融合の他に，マ イクロインジェクション, 組換え DNA 技術も検討 する予定です。

鮫島 細胞夸種法で一番難しい問題は，例えばパルプ 適木を目的とする場合、木材としての望をしい形質 を，細胞レベルでどうやって検知し，確認するかと いらことです。或る病原菌に対する抵抗性というよ らに因子が絞られている場合は, 可能性も大きいと 思いますが，木材になった後のパルプ適性といらこ とになりますと, あまりにも因子が複雑で非常に難 しい問題を含んでいます。

遗伝子操作については最近いるいる書かれていま すので御承知の方も多いと思います。植物の遗伝子 操作に使用することの出来るベクターとして, 最も 研究の進んでいるものに Ti プラスミドがあります が，宿主領域が双子葉植物に限られるということで 針葉樹などには使えそうもありません。その他に植 物ウィルスや葉緑体に, 新しい遺伝情報をのせて植 物を改良していくことが考えられます。いずれにし
ても遠い将来の仃能性といらのが現在:の知情です。 原口先利の括で葉肉新肬からのプロトプラストの 分離はなかなか難しいが，カルスからの分襍は比較 的容易であるといらことでしたが，その尖の組炎融 合といらことになりますと，どちらが可能性大とい 光真しょらか。

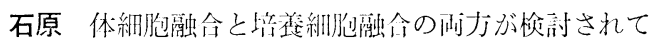
いるようですが，どちらがより大きな可能性をもっ ているのか，どちらが現在の研究の主流かといらこ とになりますと，はっきりいたしません。

鮫島 細胞融合はいずれにしても，まあやれると思い

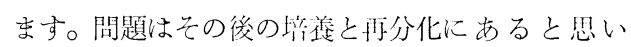
与。

\section{9. 将来への夢}

中野 林木育種といいましてもなかなか答易ではない ことがよく分りました。

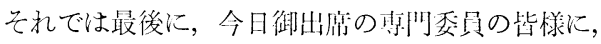
一言ずつ将来の罗を留っていただきたいと思います。 現在，バイオテクノロジーのもつ可能性がいろいろ 言われておりますが，バイオテクノロジーのどのよ らな分野に綎・パルプエ菜が入って行けるかといっ た点など，将来の可能性について述べていただきた いと思います。

諸星 将来に㧍ける醉素レベルでのリグニン生分解に 関する論点は，まず第一にリグニン分解徆孝幸の活性 中心，及びそれに対応与るリグニン化学槛造の解明 といら点他ありす。

その絬果リグニン分解源性を持った人工酵素の令 成も夢ではなくなります。更に，この人工陵浆に天

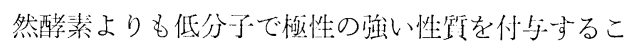
とが出来れば，リグニン分解反応も格段に高い效摔 化が達成でき，現在の企䍒レベルでも十分に利用し， また応用可能な技術となり得るものと考皇ます。

リグニンに関しては，恐らく䣼絭処理によって生 成する活性なリグニンは機能性高分于，樹脂化など による有効利用の道が開かれるかもしれません。

鮫島 まず，私が現在進めている砸究なのですが，遇

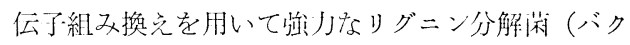
テリア）をつくりたいということです。次に，リグ ニンの生合成系，生分解系といった二次代謝系の発 現機構の解明があります。二次代䂗系の発現がコン トロール出来るようになりますと, 例えばリグニン 生分解系を常にオン $(\mathrm{ON})$ にして, リグニンの生 分解を効率的に進めることが可能となります。また， リグニンの生合成を抑制することが出来れば，リグ 
ニン含具の少ないパルブ適木を寺成することも可能 になるかと想います。

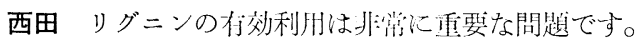
リグニン分解唒尖を䏘いて，リグニンから低分子フ エノールなどのて桨原料が生应出来たらと考光て拉 ります。そのためには，生分解機满の解明が非常に 重要ですし，人卫亚素の製造も面白いと思います。 また有機浴济に可浴な阴等素の利用なども考えてみて はどうでしょうか。

バイオロジカルパルピングにつきましては酵素を 利用することも川米をすが，私はやはり有用菌を用 いまして軽度の処理と軽度の化学処理を組又合わせ， 特徽めるパルプが製造出来たらと考えております。

阪本 從来, リグニンの生分解は分解さ无与れば，炭 睃ガスと水になっても满わないといら考光厅が強か ったわけですが，やはり存俱倠なるのに転換する研 究が必要です。その㝒味でリグニンの低分子化に関

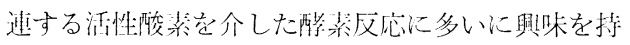
っています。ただ，バイオロジカルパルピングとい えばリグニンの分解が則さ机交すが, 必らずしも そればかりではないのではと思っております。例克 ば、リグニンとへミセルロースなどの栯鎖との結合 部位やリグニンに近掞した精鎖そのものを，優先的 に切䉼与ることもパルプ化を促進することにつなが るのではないでしょらか。

いずれにしても，21 糺にはバイオテクノロジ 一を䏳なな性ばならない将代が来ると想います。 バイオテクノロジーの大きな特徽に「熱を出さな い」ことがあります。将米，人口が增加するにつれ て熱を壮さないシステムが求められることは間違い ありませんし，その恃に林材は有力なターゲットに なりましょう。

喜多 微生物によるリグニンの分解に関しては，まだ まだ基礎研突が必要でしょら。是近の研究は非常に 活発ですので，私どもとしては応用をあせらずに注 目して行きたいと思います。

紙パルプ工壆でのバイオテクノロジーの応用とし ては, 本日出ました課題の他にスライムコントロー ルやピッチトラブルなどの面にも利用出来るのでは ないでしょらか。

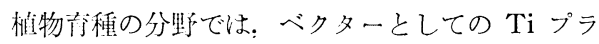
スミドの改良がかなり進展して抢り，一部の単子葉 植物での成功例も出て来て扣ります。林木去種の笑 用化はまだ相当先のことですが，草本系につきまし ては意外に旦いい牌期に莯剂耐性を付与した改良品種 が現われて来るものと想います。
大島 紙パルプ工業はやはり原木あっての産業ですの で，林木㕕種は一番重要な課題でしょら。その方法 として，細胞融合とか遗伝子操作がありますが，細 胞融合は検定に時間を要することや，どんな木が出 来るか分らないなどの問題があります。したがって， やはり遺伝子操作によらなければならないわけです。 これによって，空素固定能をもつ木や，七ルロース 分の多い木が出来るならば，紙パルプ工業の将来に とって非常に嬉しいことです。将来の林木奋種に期 待します。

上埜メタン発酵に限定した話になりますが，バイオ テクノロジーによって発酵槽内での滞留時間の短縮 及び処理条件の桩大が可能な菌が出来れば，非常に 有効だと思います。今一つは, 現在のメタン発酥で は排水中のリグニンはほとんど分解されません。リ グニンからもメタンを生成するような莉が見つかれ ば，非常に面向いのですが。

原口未利用七ルロース資源の直接発酵によって, エ タノールなどがどんどん生産出来るよらになればと 考えております。そのためには，生物的脱りグニン 技術の確立，直接発酵菌のスクリーニングが重要で す。最近の新しいバイオテクノロジ一ももらろん重 要ですが，有用な菌のスクリーニングといった努力 も忘れてはなりません。

中野卆れでは最後に石原さんに御発言を願います。

石原 最近，バイオテクノロジーがいろいろな分野で 望られています。バイオロジカルパルピングが KP にとって代ることは，私は将来とも起こらないと思 います。しかし，微生物の利用は紙・パルプ工業に 捻いても: いろいろな面で盛んになると思います。 例えば，林木青種についてはこれから非常に進少す ると思いますが，将来を予测することは誰にも出来 ないのではないでしょうか。リグニンを微生物的に 分解して有用な低分子フェノールを生産することを 願望しているのですが。

今一つ, いわゆる褐色腐朽菌といらものがあり, これはリグニンを分解せずに，糖を分解するわけで す。この場合, ぞうやって褐色腐朽菌がリグニンバ リアーを透過して，糖の部分に到達しているのか， 常に非常に興味深く思っている次第です。

中野 以上で専門委員の方々の御発言は一通り終りま した。何か補足的意見などございますでしょうか。

角 紙・パルプ工業にとって，バイオテクノロジーの 究極の技術はセルロースの生合成ではないかと思い ますが，これは可能なのか，或いは全く不可能なの でしょらか。 
石原 現在，デンプンを試験管内で生合成しょうとい ら研究をしている方々がおられます。セルロースの 生合成としては，酷酸菌を用いた研究がありますが 本材セルロースとは異なります。ただ，いずれにし ましてもセルロース生合成の出発物質としてグルコ 一スを使用するとなりますと，そのグルコースを何 からつくるのかといら点で問題があると思います。

\section{おわりに}

中野 皆さんに「将来への夢」を就話し願ったところ

で，この座談会も閉会を迎光ます。

私は日本紙パルプ研究所の浅岡研究所長と「紙パ ルプ技術予測研究会」を運営していますが，最近第 3 回の調查を行い, 去る 9 月 4 日に「シナリオ法に よる 2001 年の紙パルプ産業の技術予測」の発表会 を行いました。

このなかの一つとして, 紙パルプ工業とバイオテ クノロジーに関する設問があったのですが，回答者 の多くはバイオテクノロジーはパルプ原料に大さく 員献しないであろらということでした。

しかし，現在バイオテクノロジーには莫大な研究 投資が行われていますから，21世紀のいつかには， 紙・パルプ工業にインパクトが現われるものと考え て㧍ります。将来的にはパルプ原木用の早生樹が出
現し，また素晆しいリグニン分解菌や醉点が現われ ることを待ち望んで居ります。原理似何能なもの は，人類は歴必のなかで必ず皮現させてきたことも 事実です。

それでは皆さん本日は御多忙のところ御出席をい ただきまして大変有難ら佔じました。

\section{木材科学委員会委員}

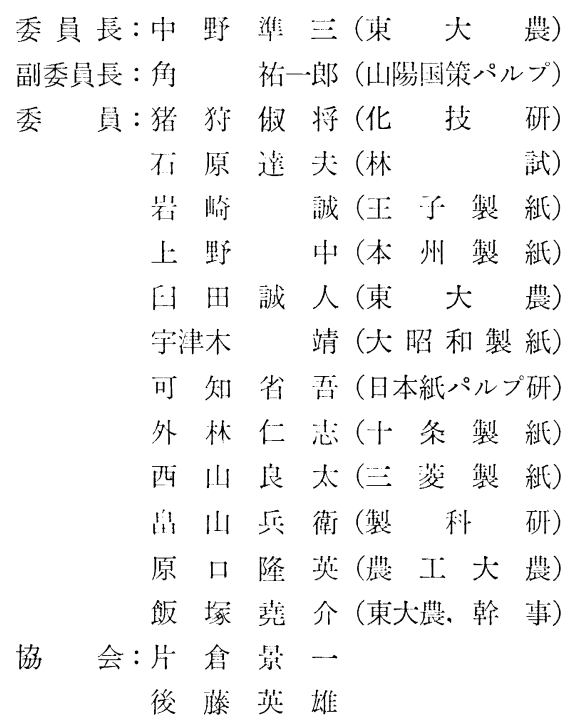

